\title{
ABSTRACTS
}

\section{PAMEla ARMSTrong}

$295-335$

\section{Byzantine Thebes: excavations on the Kadmeia, 1980 (Plates 29-36)}

In May and June 1980 Dr K. Demakopoulou undertook exploratory excavations on behalf of the Greek Archaeological Service in the central square of the city of Thebes. Deposits of the Byzantine and later periods continued down for more than 5 metres. The finds, primarily from domestic habitation, are presented here.

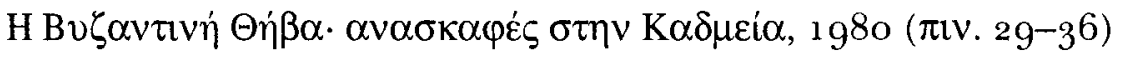

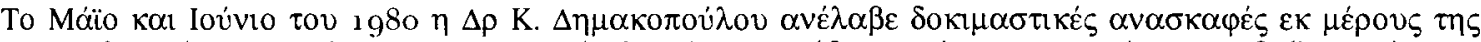

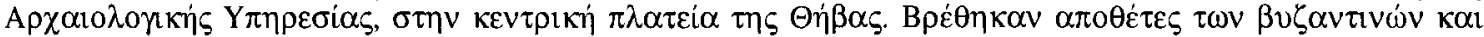

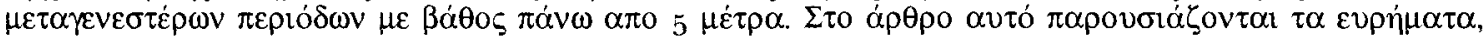

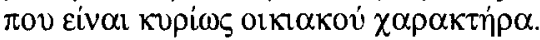

Donald M. Bailey

$221-49$

Excavations at Sparta: the Roman stoa, 1988-91. Preliminary report, part 1. (b) Hellenistic and Roman pottery

The pottery described comes from areas of the Roman stoa that were selected by the excavators as important. Most groups contained quantities of local tiles, glazed or unglazed, and large numbers of unidentifiable body sherds. The vast majority of the pottery was locally made and is micaceous, normally very micaceous. Its normal colour is orange of various shades, but it can be a light brown; fired in a reducing atmosphere the body is grey, and this can have a grey slip. There was considerable use of black glaze and red-to-brown slip on Laconian vessels, both coarse and fine; black glaze seems to have been in use at Sparta well into the ist cent. AD. The generally late hellenistic and Roman Laconian vessels from these contexts are largely unknown archaeologically, and dating is thus at a preliminary stage. Very few imports were found, but these represent the main dating criteria. The hellenistic and Roman pottery found in the Roman stoa, limited as it is, can only be regarded as material for the beginning of a corpus of the many local forms of the period.

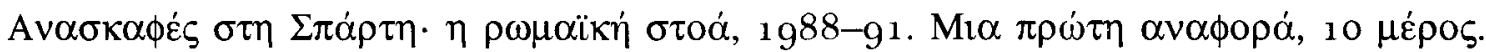

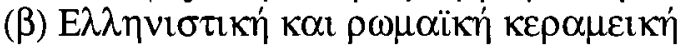

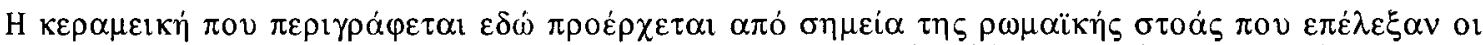

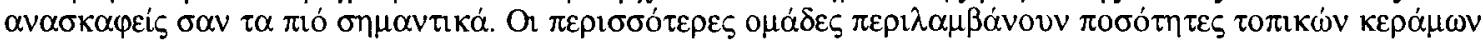

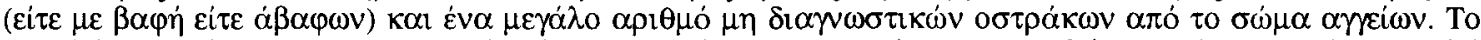

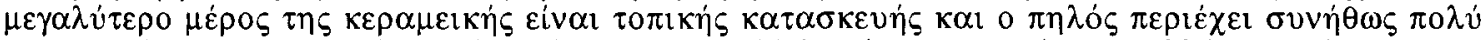

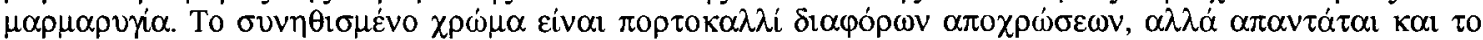

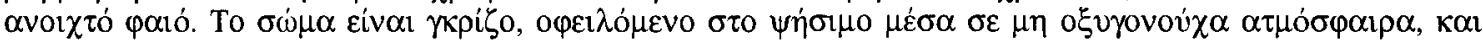

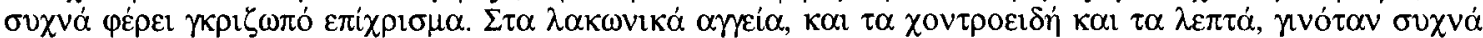

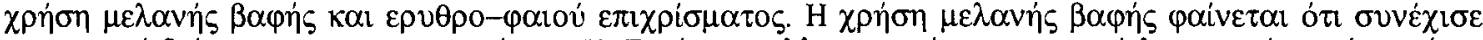

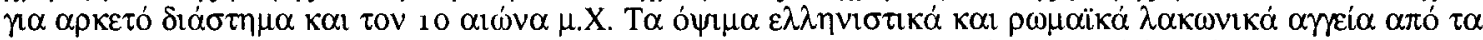

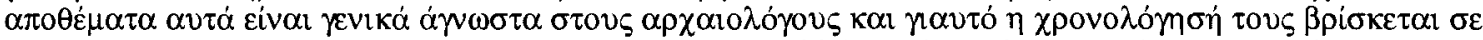

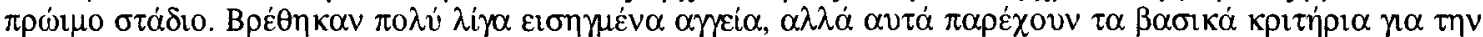

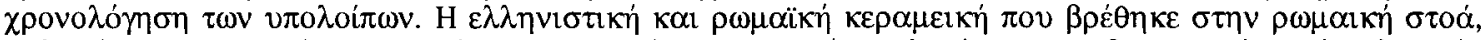

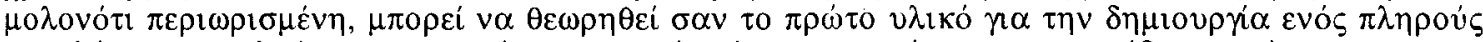

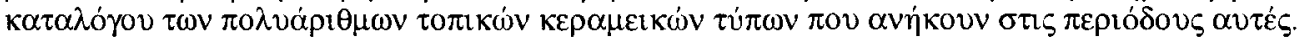


G. Cadogan, P. M. Day, C. F. MacDonald, J. A. MacGillivray, N. Momigliano, T. M. Whitelaw, and D. E. Wilson $21-8$

\section{Early Minoan and Middle Minoan pottery groups at Knossos}

This paper is a summary of the results of a workshop held at Knossos in August 1992. The aims of the workshop were to examine the most coherent and reliable deposits, place them in a chronological sequence, and decide on common terminologies and definitions. This brief paper provides a framework and serves as a common introduction to various detailed studies of Knossian EM-MM pottery by the various authors which have appeared, are in press, or are forthcoming.

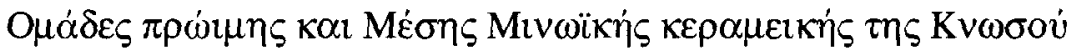

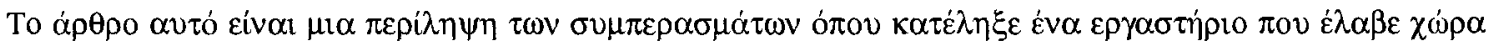

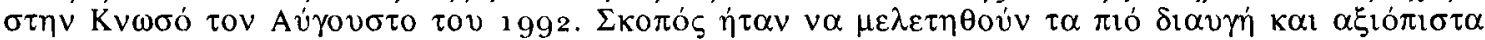

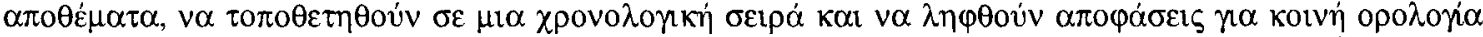

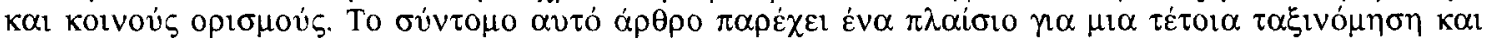

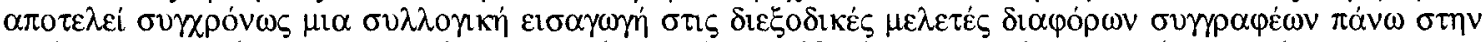

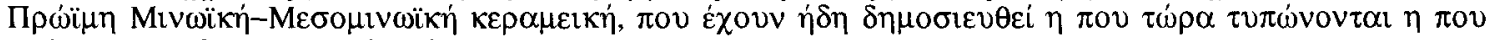

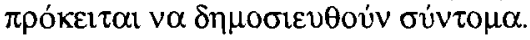

\section{B. F. CoOK}

\section{The Parthenon, east pediment A-C (Plates 1 7-18)}

A new examination, prompted by Dr Peter Calligas, of Parthenon East Pediment C (two horses of Helios), suggests that the underside was trimmed when the group was installed in the pediment. The recutting of pedimental sculptures of the Parthenon to fit beneath the raking cornice is well attested for other figures, but has not previously been suggested for this block.

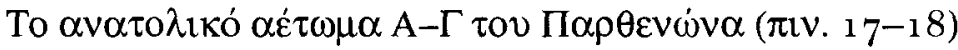

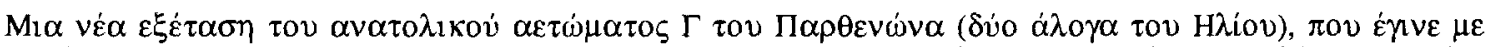

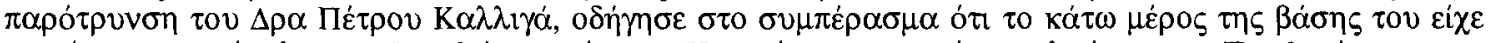

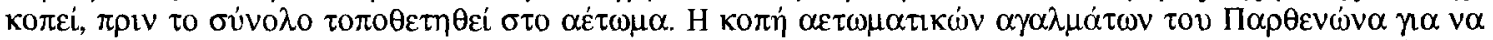

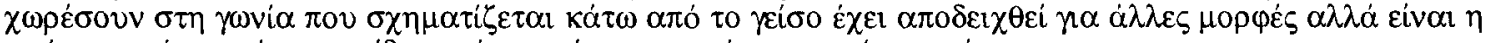

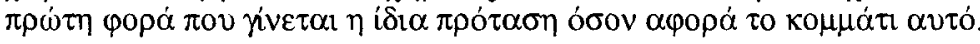

\section{Nikos Efstratiou}

$135-71$

The archaeology of the Greek uplands: the early iron age site of Tsouka in the Rhodope mountains (Plates $7-16$ )

The upland areas of Greece have long been outside the main focus of archaeological interest. With regard to prehistoric research, mountains were never seen as potential habitation areas, and recovery techniques had to address unusual environmental and geomorphological situations. Research in the Rhodopi mountains initiated by Komotini Museum attempts to illustrate some aspects of this upland archaeology. This article presents the results of excavation at an early iron age site which appears to give an insight into the habitation behaviour of the Thracian mountain population at the end of the 2nd millennium BC. It is proposed for the first time that a number of the so-called Thracian places found scattered all over the Rhodopi mountains are not, as at first thought, fortified acropoleis but sites with special functions, serving an agricultural and pastoral economy. It is further suggested that ethnoarchaeological observations can serve as valuable explanatory hypotheses which can be tested against the available excavation data. 


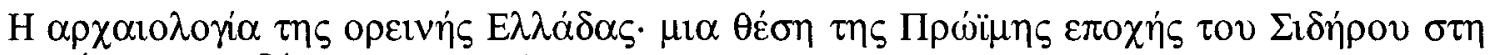

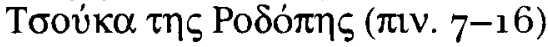

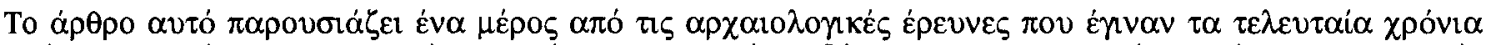
a

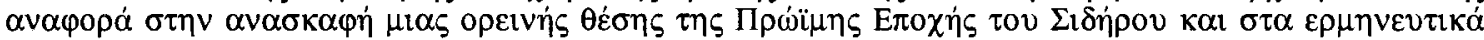

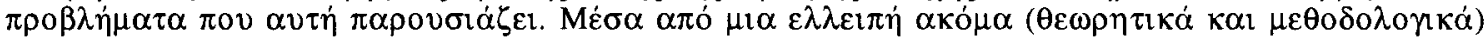

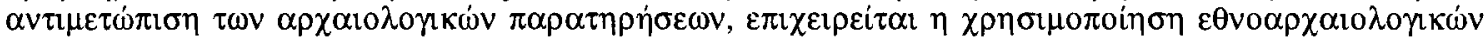

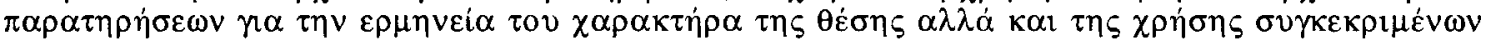

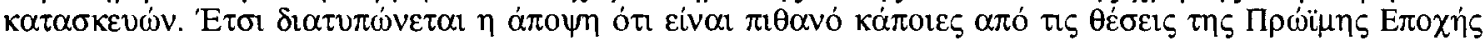

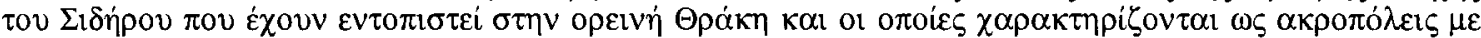

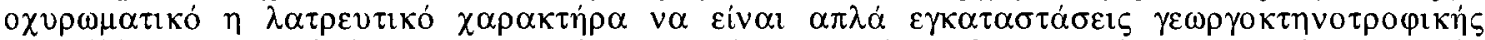

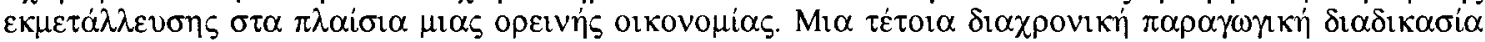

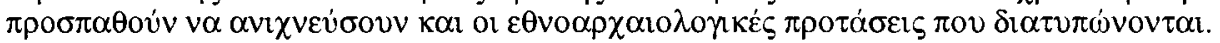

David W. J. Gill.

$173-81$

The temple of Aphaia on Aegina: further thoughts on the date of the reconstruction

The publication of further ceramic material from the terrace fills surrounding the temple of Aphaia on Aegina brings into question the present date assigned to the reconstruction by the excavation team. The cumulative effect of black-figured, red-figured, and black-glossed pottery, as well as lamps and amphorae from the terrace fills, seems to indicate that the temple may be later than the Persian wars. Much of the late material finds parallels from contexts in the Athenian Agora which are usually thought, on the conventional chronology, to date from the time of the Persian wars. If the revised views of these contexts are taken into account, then the temple of Aphaia may have to be dated lower still.

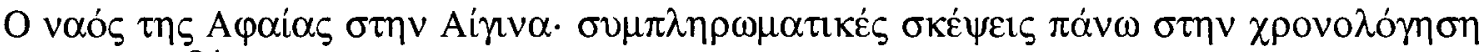

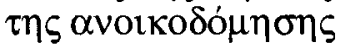

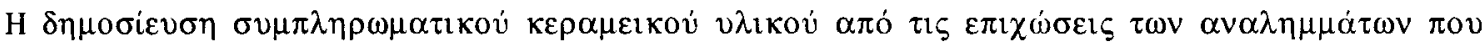

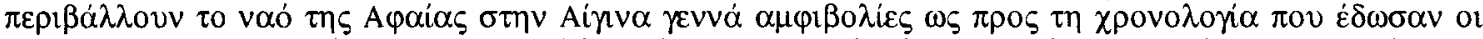

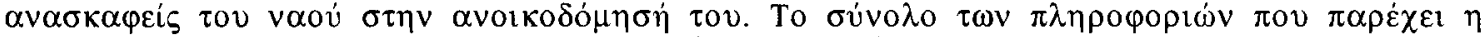

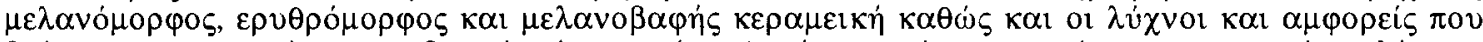

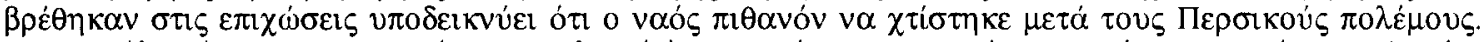

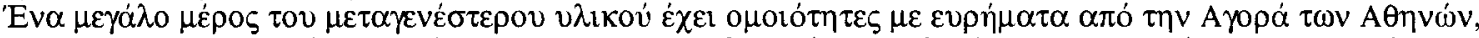

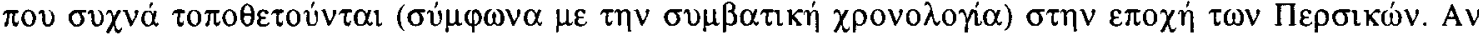
$\lambda \alpha \dot{\beta} 0 v \mu \varepsilon v \pi^{3}$ ó $\psi \eta \tau \eta v \alpha v \alpha \theta \varepsilon \dot{\rho} p \eta \eta \eta$

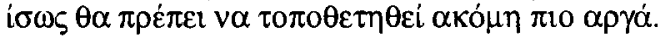

\section{Garth GiLmour}

$125-34$

\section{Aegean sanctuaries and the Levant in the Late Bronze Age}

In a recent paper by $\mathrm{O}$. Negbi it was argued that certain late bronze age Aegean temples owe elements of their design to influence from the Levant. Architectural features such as corner platforms, a 'bent-axis' approach, and twin temples, and cultural features such as the presence of 'smiting god' figurines, are analysed. It is concluded that there is no evidence that Aegean shrines were built according to a Canaanite model, and that there was no Canaanite cultic influence in the Aegean during the Late Bronze Age. If anything, the reverse applied in the early Iron Age, when the influence of the Sea Peoples is seen in some cultic architecture in the Levant.

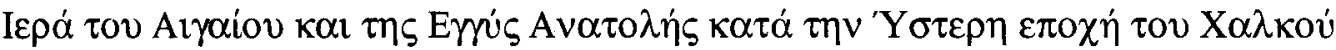

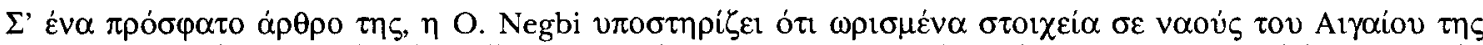

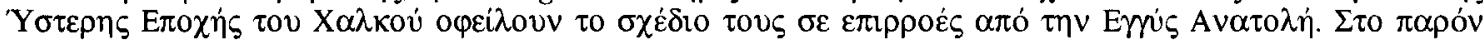




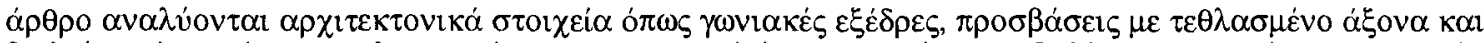

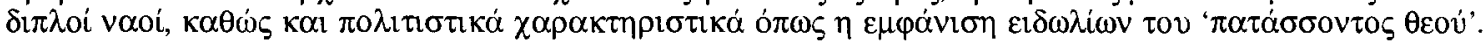

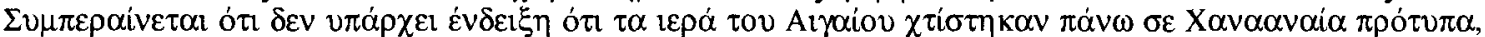

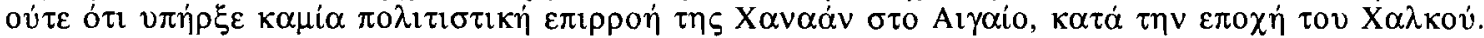

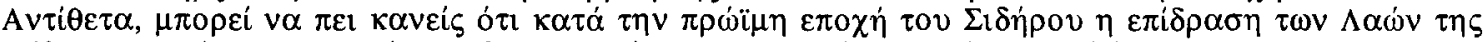

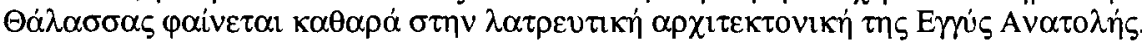

Glynis Jones and Paul Halstead

$103-4$

An early find of 'fava' from Thebes

A polychrome style krater from an LH I A destruction level in Thebes contained charred seeds of Vicia faba L. (field bean), which had been split in the manner of Greek 'fava' ( $\phi \alpha \dot{\alpha} \beta)$. The growing archaeological evidence for late bronze age consumption of pulses contrasts with their absence from the Linear $B$ archives. Consumption of the field bean as fava affects the intake of toxins which may cause lethal anaemia, but may also afford protection against malaria.

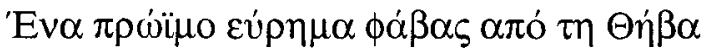

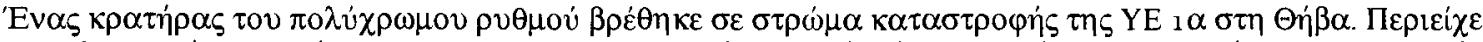

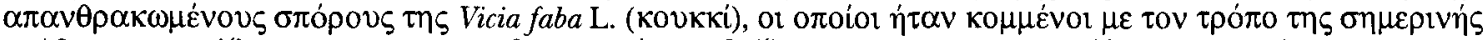

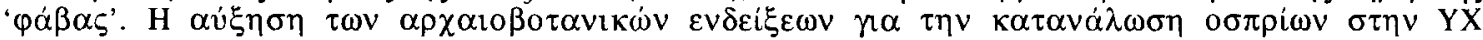

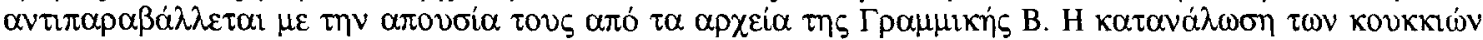

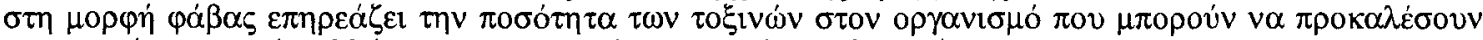

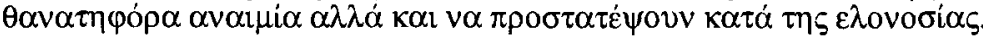

\section{Glynis Jones and Paul Halstead}

Charred plant remains from neolithic-bronze age Platia Magoula Zarkou, Thessaly

Charred plant remains of middle neolithic to middle bronze age date indicate the processing for storage or consumption of emmer (Triticum dicoccum), hulled six-row barley (Hordeum vulgare), bitter vetch (Vicia ervilia) and acorns (Quercus sp.). Samples of emmer, barley, and bitter vetch from an early bronze age destruction level are valuable evidence for economic diversification at a household level.

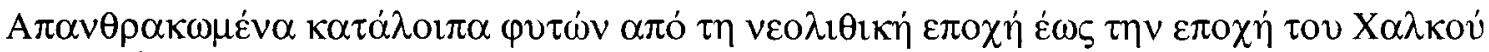

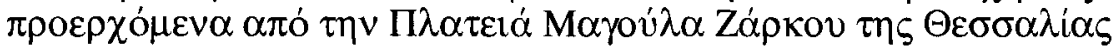

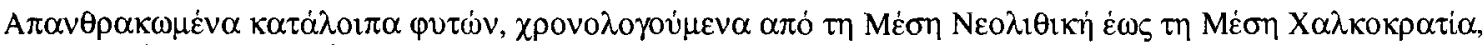

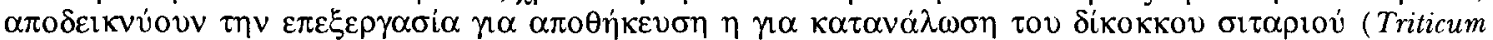

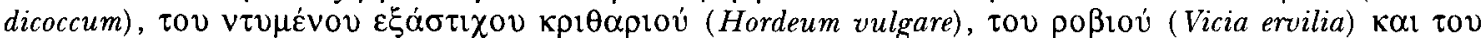

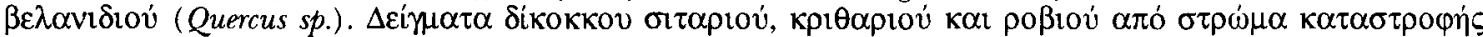

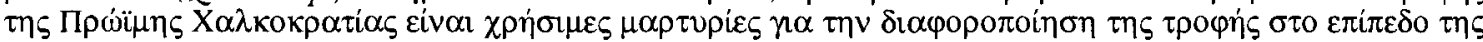

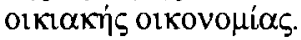

\section{KATERINA KOPAKA}

$93-102$

\section{New evidence on the pottery from the early excavations at the palace of Knossos}

The aim of this paper is to present some new evidence on the pottery discovered during the very first exploration of the Palace of Knossos, conducted in 1878-9 by Minos A. Kalokairinos. It deals with a series of drawings executed by John L. Myres on his visit to the excavator's collection in 1893 . The drawings are kept in the Ashmolean Museum archives and depict a total of twenty-one sherds (ten of which were already known from previous publications) and one whole vase. 


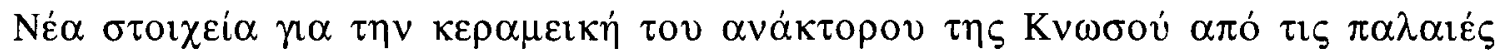 $\alpha \vee \alpha \sigma \kappa \alpha \varphi \varepsilon ́ \varsigma$}

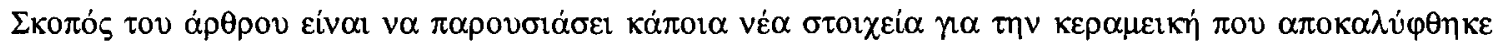

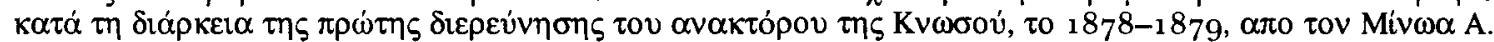

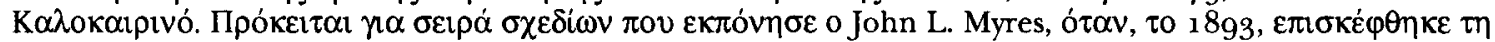

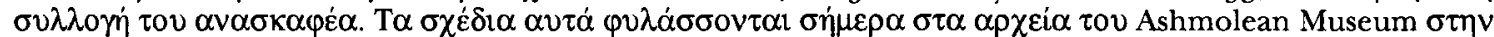

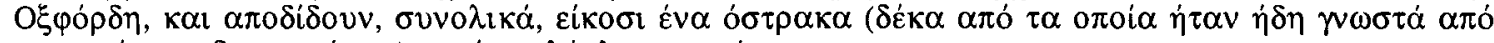

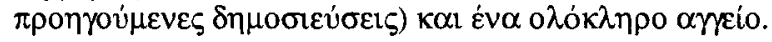

\section{A. Leonard, M. Hughes, A. Middleton, and L. Schofield}

$105^{-23}$

The making of Aegean stirrup jars: technique, tradition, and trade (Plates 1-6)

This paper presents the results of a project designed to investigate the techniques used to make late bronze age Aegean stirrup-jars and to determine whether the identified techniques were influenced by regionalcultural factors. The project was initiated by the need to address the question of whether 1 ath-cent. BC stirrup-jars from Tell es-Sa'idiyeh in the Jordan valley, apparently of local clay, were made by local potters or by immigrant Mycenaeans. The stirrup-jars studied comprised examples from Tell es-Sa'idiyeh, Gezer, the Greek mainland, Aegina, Rhodes, Cyprus, Caria, and Egypt. Xeroradiography was used to elucidate variations in construction techniques, and the findings were tested by practical experimentation. The observations indicate that there is a degree of linkage between the techniques of manufacture and cultural background. In order to make the discussion of production techniques more secure, neutron activation analyses were also carried out; these provided information on the place of manufacture as opposed to the find-spot, and have also thrown some interesting light on patterns of trade in the Mediterranean area towards the end of the Late Bronze Age.

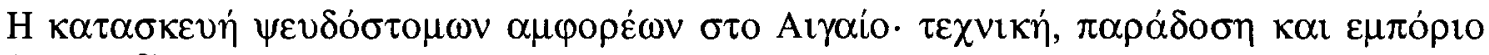
$(\pi \mathrm{iv.} \mathrm{1-6)}$

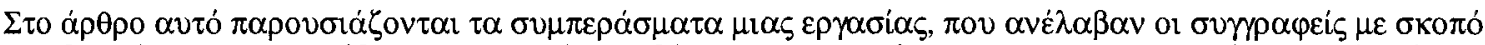

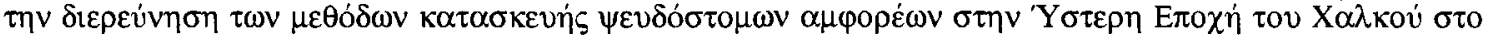

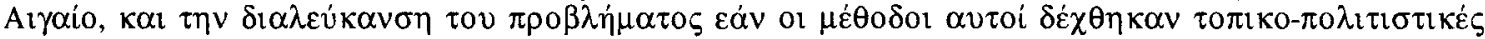

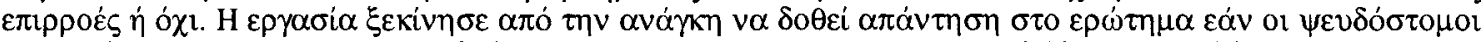

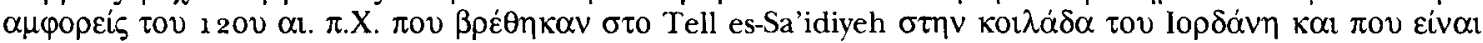

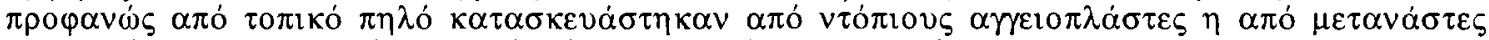

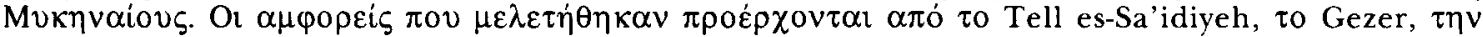

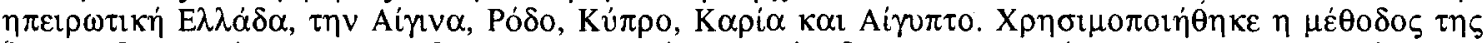

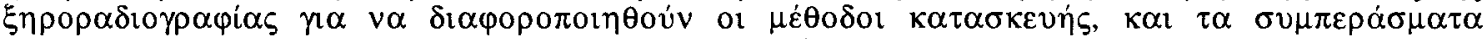

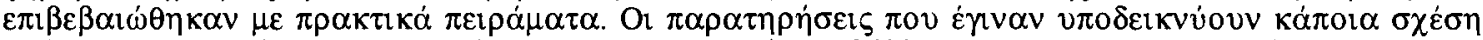

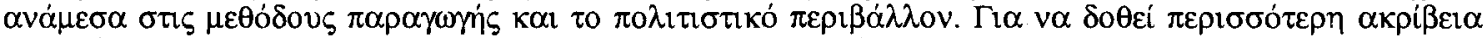

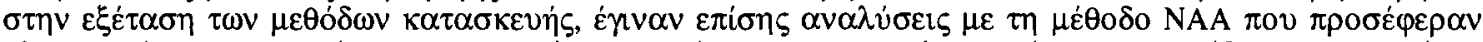

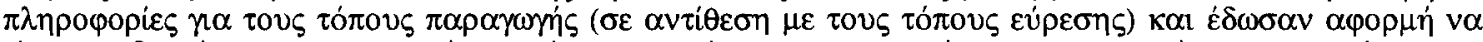

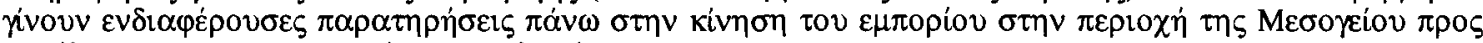

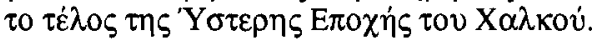

\section{Missailidou-Despotidou}

$187-217$

A hellenistic inscription from Skotoussa (Thessaly) and the fortifications of the city (Plates 19-22)

In 1983 the Larisa Museum received an inscribed stele, purporting to be from the farming area of Agia Triada. Even today, parts can be seen in this area of the fortifications of an ancient city, thought to be the Thessalian Skotoussa. The inscription comprises 154 lines, and is written in the Thessalian (Pelasgian) dialect; it dates from 197-185 BC. It is a decree of the city (which is now proved to be Skotoussa), and 
concerns the description of a zone inside and outside the city walls, which was to contain no privately owned land. The decree was passed as part of the reorganization of the defences of the city after the collapse of Macedonian supremacy in the region. The zone was defined in detail using as reference points the towers, distances between the towers, and other sections of the walls, as well as parts of the city adjoining the wall. The result of such a systematic body of cross-reference is a description of nearly the whole of the city's fortifications. Following a topographic survey of the Agia Triada region, and taking into account older surveys, a restoration of the course of the wall is attempted. Using the inscription as a guide, a comparison is made between the sections of the wall that are described, together with other place-names appearing in the inscription, and the surviving ruins at Agia Triada.

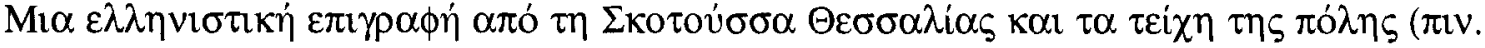 19-22)}

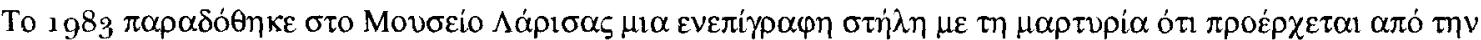

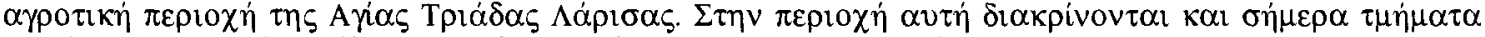

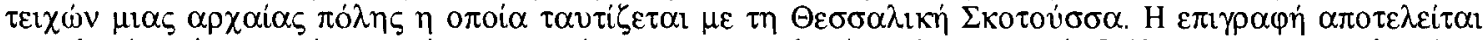

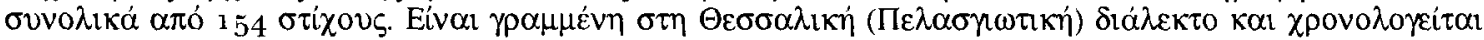

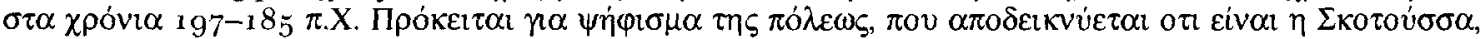

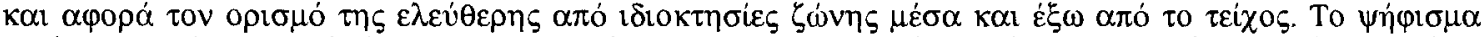

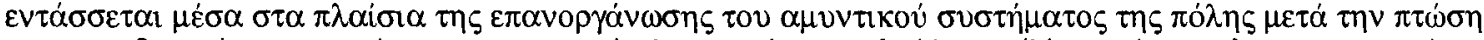

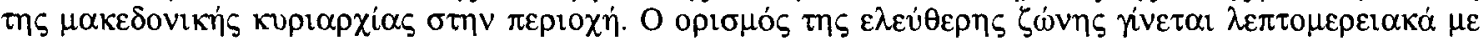

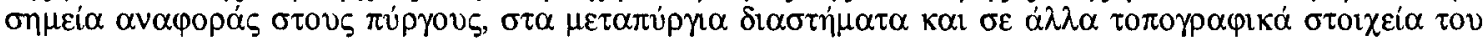

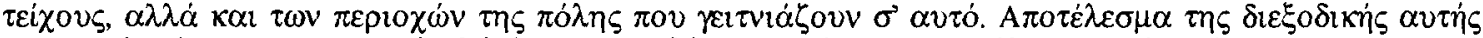

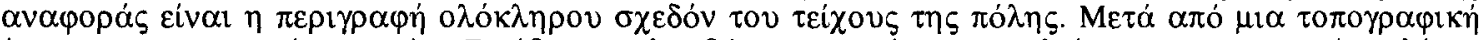

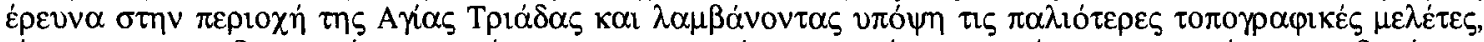

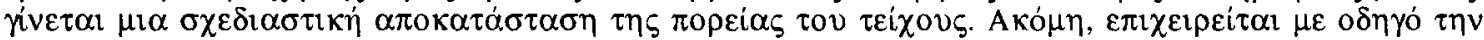

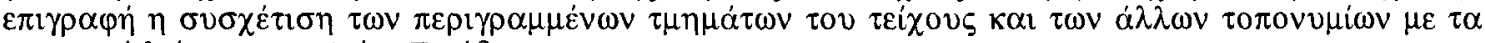

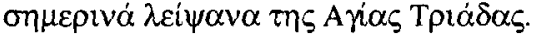

\section{MARINA PANAgIOTAKI}

Sealings from the Olive Press Room, Knossos: new information from the unpublished notes of Sir Arthur Evans

This paper is based mainly on an unpublished page with drawings, made by Arthur Evans, dealing with sealings recovered from the Olive Press Room, Knossos. In order to date the sealings identified through Evans's drawings, an attempt is made to place them in their correct stratigraphic perspective; this is done by studying the stratigraphy of the Olive Press Room as presented by Evans in two of his notebooks.

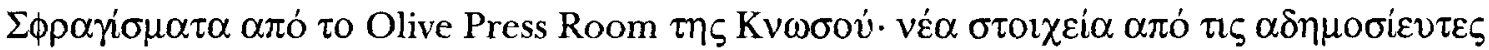

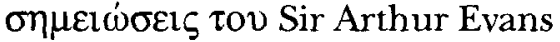

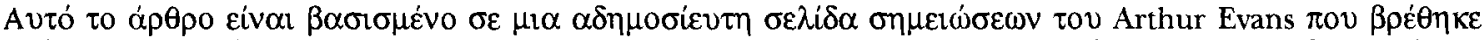

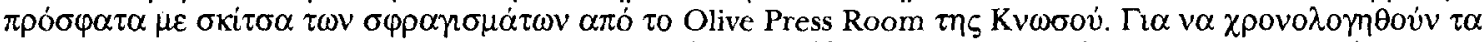

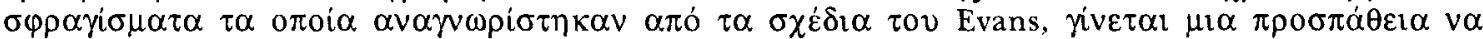

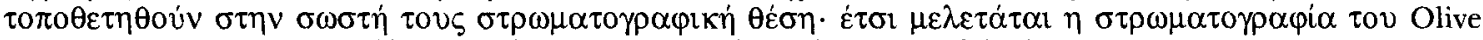

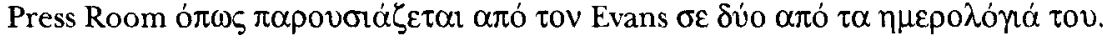

\section{Marina Panagiotaki}

The Temple Repositories of Knossos: new information from the unpublished notes of Sir Arthur Evans

A set of notes found in the Ashmolean Museum Archives, unknown until now, and written by Sir Arthur Evans, has provided the basis for this paper. In them, Evans made annotated drawings of the most important objects recovered from the Temple Repositories of the Palace at Knossos, as well as of the Repositories 
themselves. Some ideas and issues developed in Evans's subsequent publications can be traced in their first forms in these notes. It is very significant that next to each drawing Evans wrote a figure, evidently the total of similar objects-something he did not do to such an extent in the publications. The section dealing with the sealings may reveal their actual number, as well as a certain confusion between the actual impressed surfaces and the sealings themselves. Reproductions of Evans's pages, transcriptions, and the author's comments on important points make up the bulk of the article. A more complete and enlarged corpus of the objects is now feasible; here an abbreviated catalogue of the newly identified objects is appended.

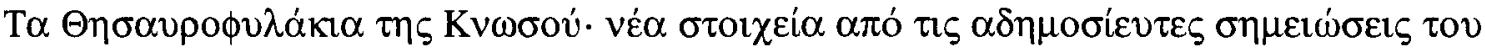
Sir Arthur Evans

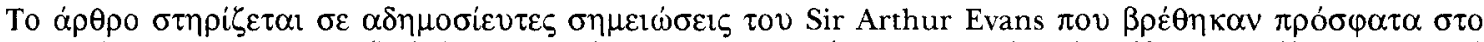

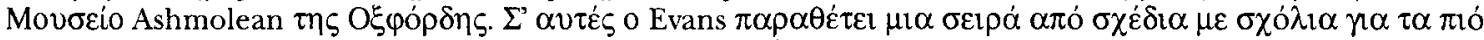

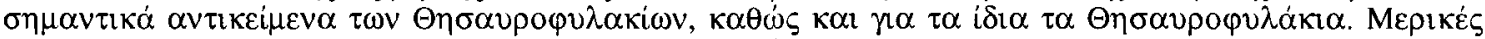

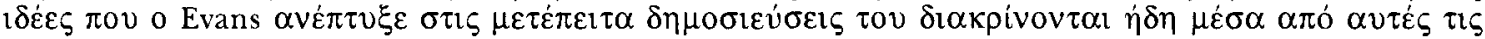

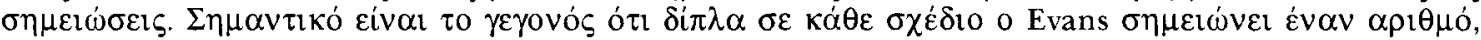

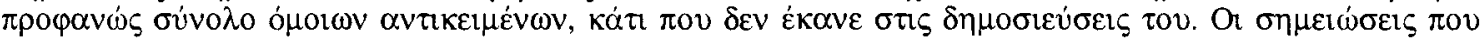

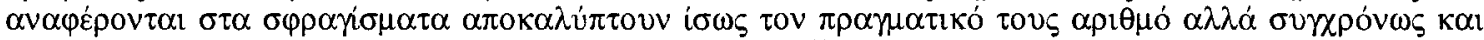

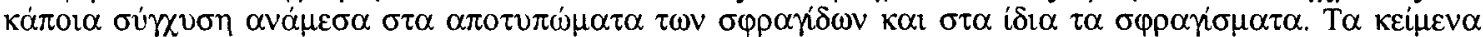

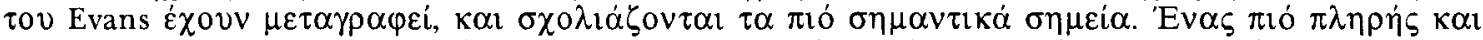

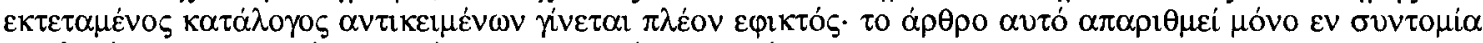

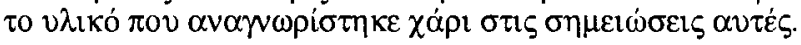

\section{John K. Papadopoulos}

The correspondence of A. J. B. Wace in the library of the Australian Archaeological Institute at Athens

In 1986 a donation of books deriving from the library of A. J. B. Wace was presented to the Australian Archaeological Institute at Athens. It was Wace's habit to keep some of his correspondence with scholars and friends in books either written by those scholars or closely connected with their work. Over fifty letters and other papers were tucked away in eight volumes, mostly dating from $1946-5^{1}$ though including some earlier items. The correspondence deals with a wide range of subjects of some archaeological and historical interest, and includes several letters from Ernst Meyer, here transcribed in full. The correspondence is catalogued here, and indexes are provided.

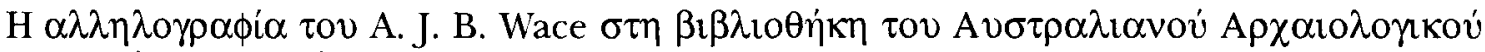

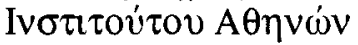

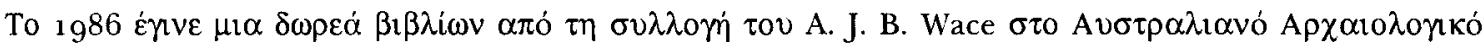

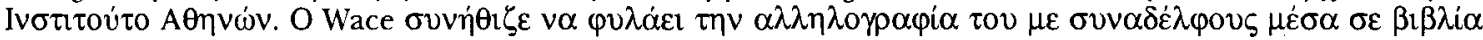

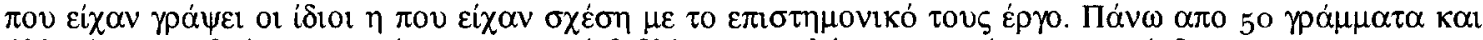

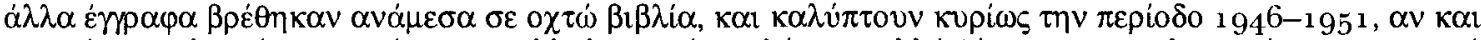

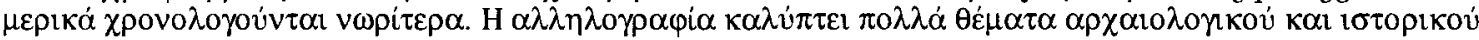

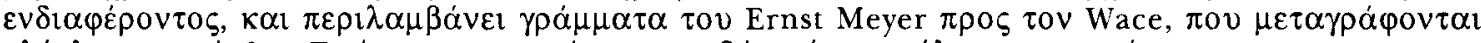

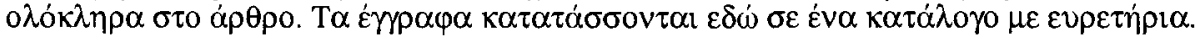

\section{G. D. R. SANDERS}

$25^{1-86}$

Excavations at Sparta: the Roman stoa, 1988-91. Preliminary report, part 1. (c) Medieval pottery (Plates 23-6)

Contexts recently excavated by the BSA in the Roman stoa at Sparta contain pottery dating from the 12 th to early $14^{\text {th }}$ centuries. The bulk of the material dates to the first half of the $13^{\text {th }}$ cent., and demonstrates that certain styles of pottery decoration, once considered to be mainly 12 th-cent. in date, continue in currency much longer. These contexts show that Champlevé (Morgan's 'Incised ware') decorated with animal 
xviii

ABSTRACTS

motives in the tondo are companion pieces of Glaze Painted (Morgan's 'Green and Brown Painted group V') and late Slip Painted wares. The descriptively (but confusingly) named 'Protogeometric' style of plainware decoration is also one that remains in currency. Cooking-vessels are almost exclusively handmade, in a very coarse fabric evocative of so-called 'Slavic' pottery of the 7 th cent., with which it may well be confused. Table amphoras (stamnia) and small pithoi are often decorated with a distinctive incised decoration, making handles and body sherds of this usually nondescript and conservative shape particularly identifiable and diagnostic.

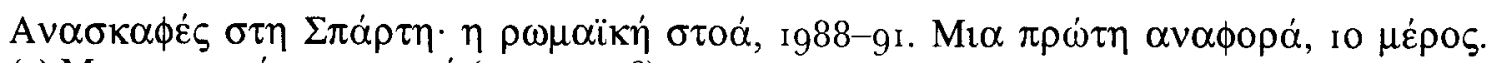

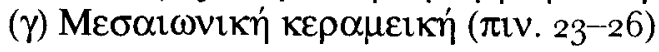

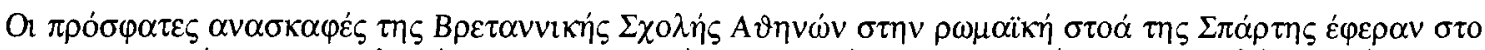

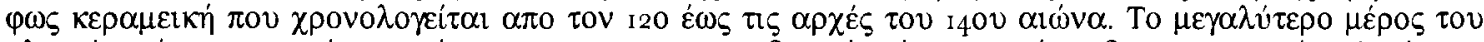

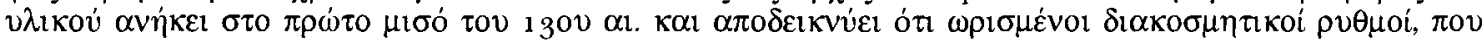

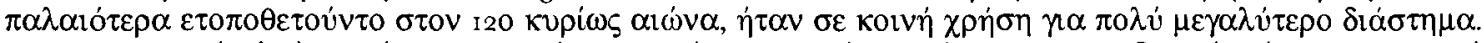

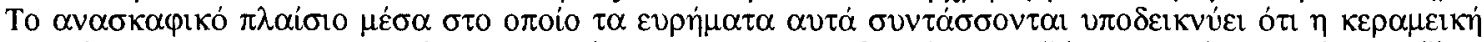

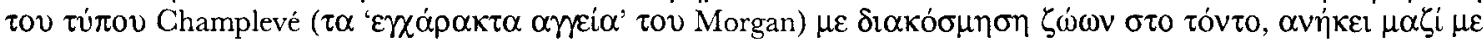

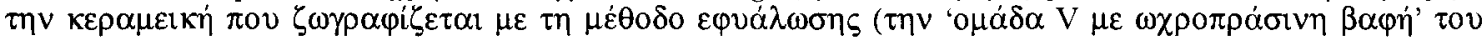

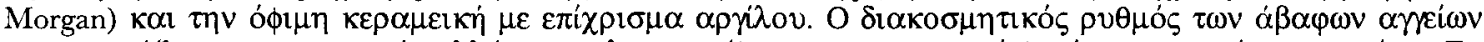

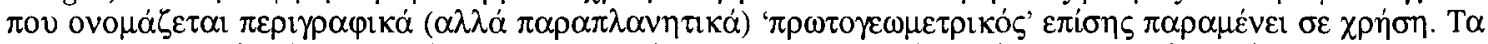

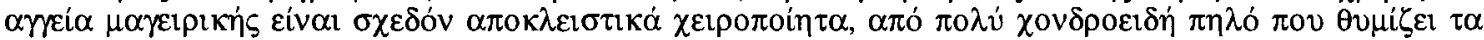

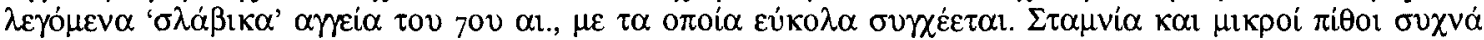

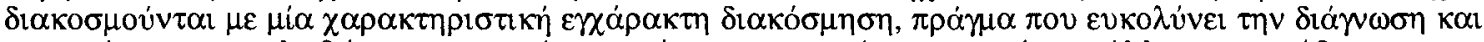

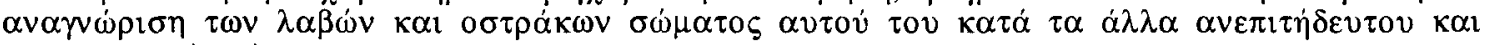

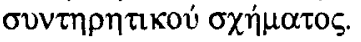

\section{Panayiota Sotirakopoulou}

$5^{-20}$

\section{The chronology of the 'Kastri group' reconsidered}

The single ceramic phase of the Aegean Early Bronze Age known as the 'Kastri group' has been dated by scholars either to an early phase of EB 3 or to the late phase of EB 2. However, careful examination of the contextual associations of the characteristic pottery of this group in the Cycladic islands and the mainland, and detailed analysis of the ceramic forms and features first appearing in this phase, show the 'Kastri group' pottery to occur, as a rule, with forms of EB 2. It is also shown that either this pottery itself, or certain forms with which it occurs, present features heralding EB 3. It is thus proposed that the 'Kastri group' constitutes a transitional phase of apparently short duration, intermediate between EB 2 and 3, overlapping in date with both the last stages of the former and the early stages of the latter and 'bridging' these two periods.

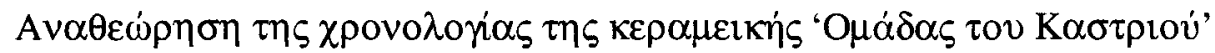

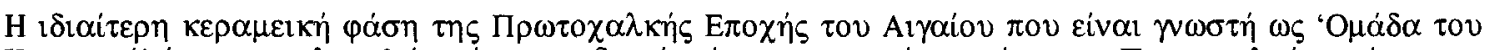

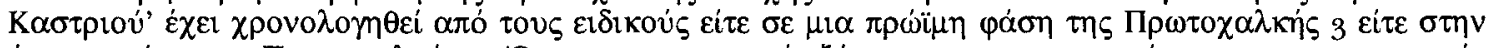

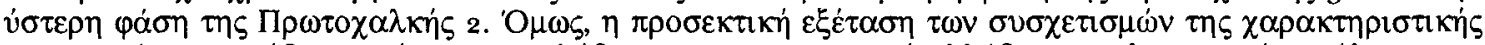

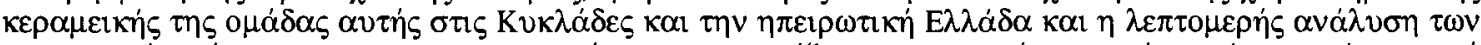

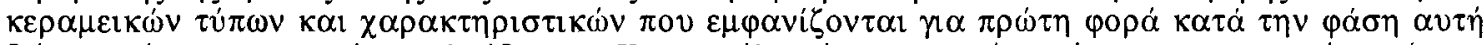

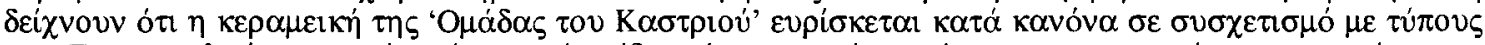

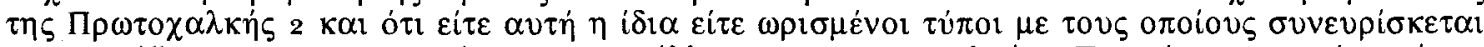

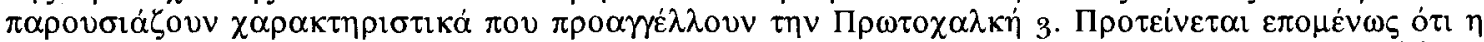

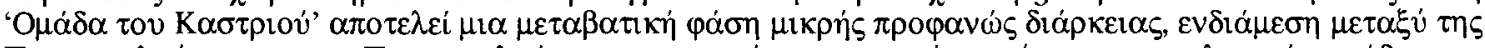

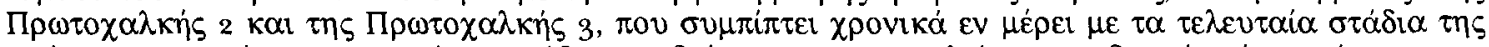

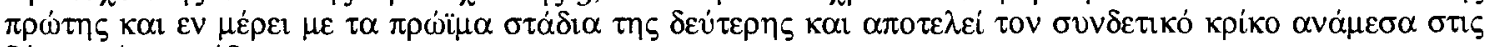

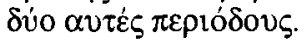


Olga Vassi

An unglazed ware pottery workshop in twelfth-century Lakonia (Plates 27-8)

During a rescue excavation in the village of Magoula near Sparta, a pit was revealed which contained a heap of fragments of large and small vessels, the products of an unglazed ware pottery workshop. This paper presents the distinctive features of the workshop; the characteristic incised decoration on the strap-handle is considered its 'trade mark'. The operation of the workshop is dated to the first half or the middle of the 12 th cent., and its production is identified in large closed vessels (stamnia) and small jugs for everyday use.

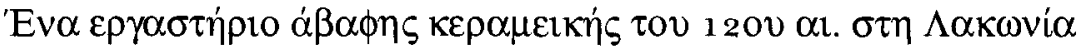

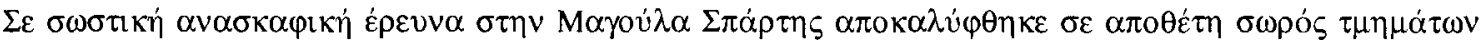

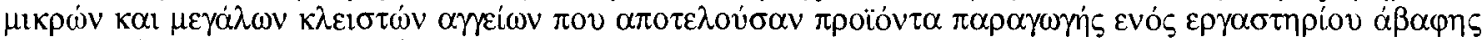

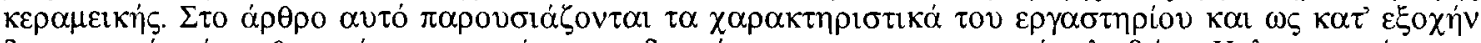

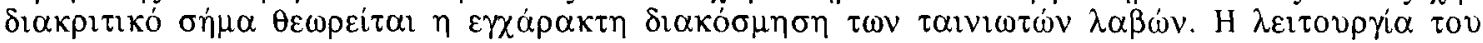

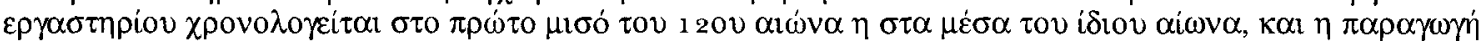

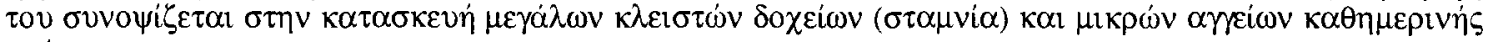
xpírns.

\section{G. B. WAYWELL and J. J. Wilkes}

Excavations at Sparta: the Roman stoa, 1988-91. Preliminary report, part 1. (a) Introductory remarks

In a brief note, the excavations are described and the pottery studies by D. M. Bailey and G. D. R. Sanders are introduced.

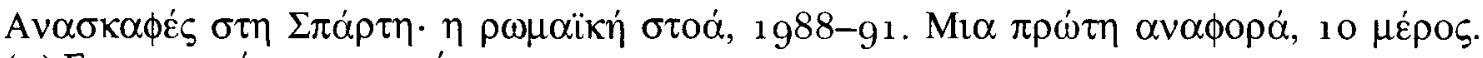

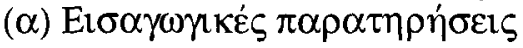

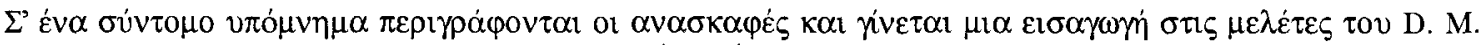

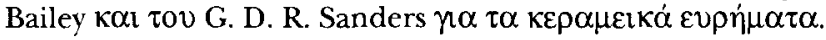

